\title{
O MEANDRACH IDENTYFIKACJI ŚREDNIOWIECZNYCH NAZW WODNYCH NA PÓŁNOCNO-WSCHODNIM I WSCHODNIM MAZOWSZU
}

Słowa tematyczne: hydronimia, Mazowsze wschodnie, Mazowsze północno-wschodnie

Niniejszy artykuł ma na celu przybliżenie badaczom późnośredniowiecznego osadnictwa i nazewnictwa Mazowsza północno-wschodniego i wschodniego niebezpieczeństw kryjących się we współczesnych opracowaniach hydrograficznych i hydroonomastycznych.

Jego podstawą źródłową są poświadczenia nazw wodnych we wpisach aktów nadań dóbr, ich kupna, sprzedaży lub zamiany do Metryki Koronnej w XVXVI w., w mniejszym stopniu pochodzące z innych źródeł powstałych w tym samym okresie oraz nieco później. Odniesieniem będą natomiast ustalenia zawarte w dwóch podstawowych publikacjach omawiających hydronimię tego obszaru, a mianowicie w opracowaniach Ewy Bilut (1995) i Marii Biolik (2005a), a także w „Hydronimii Wisły” (1965) i w „Atlasie podziału hydrograficznego Polski” (APHP) oraz w kilku innych pracach historyków i toponomastów.

W dwóch pierwszych opracowaniach daje znać o sobie słaba znajomość dziejów i geografii badanego obszaru oraz źródeł pisanych, spotęgowana wyrywaniem nazw wodnych z kontekstu przekazu pisanego. Brak jest też weryfikacji starszych ustaleń. Prowadzi to do mylenia poświadczeń źródłowych, złej identyfikacji i lokalizacji cieków oraz do pomijania wielu nazw ${ }^{1}$. W „Hydronimii Wisły” brakuje nazw licznych cieków i częste są złe ich lokalizacje, a w atlasie hydrograficznym natrafiamy na bardzo ograniczoną znajomość historycznej hydronimii i zastępowanie jej sformułowaniami opisowymi. Aby nazwać drobniejsze cieki, przywołuje się nazwy wsi, w pobliżu których mają one obecnie źródła, na przykład zamiast Lachowegostoku odnajdujemy Dopływ spod Lachowa (nr 26 47834), zamiast Bystregostoku - Dopływ spod Truszek (nr 2647832), zamiast Gromadzynegostoku - Doptyw spod Gromadzyna Stare-

1 Por. E. Kowalczyk-Heyman (2008), rec.: M. Biolik (2005a, 2005b). 
go (nr 2649861)². Natrafiamy również na rozbieżne ustalenia odnośnie do źródeł i górnych biegów niektórych z nich przez mylenie ich z górnymi dopływami.

Porównanie hydronimów znanych ze średniowiecznych przekazów pisanych z nowożytnym i dzisiejszym nazewnictwem wodnym ukazuje w wielu przypadkach dużą ich zmienność, głównie w odniesieniu do mniejszych cieków. Wiele nazw zaginęło, zanikło lub zostały zastąpione przez nazwy nowe, derywowane (np. Stucz $>$ Stuczka $>$ Stuczanka) lub utworzone od innych podstaw (np. Stucz $>$ Matlak). Zadaniem badacza jest zatem ukazanie tej zmienności i przypisanie konkretnych nazw i ich poświadczeń właściwym ciekom. Pomocą służy tu identyfikacja i położenie wsi powstałych na badanym obszarze głównie w XV w., bowiem w celu określenia należących do nich gruntów, w opisach nadanych, kupionych lub sprzedanych dóbr podawano zwykle nazwy cieków lub wymieniano granice wsi już wówczas istniejących, a sąsiadujących $\mathrm{z}$ tymi dobrami. Ponadto wiele $\mathrm{z}$ założonych wsi nosiło początkowo nazwy ponowione od płynących obok strumieni, np. Czarnocinstok (późniejsze Czarnocino/Czarnocin), Lachówstok (dzisiejsze Lachowo), Czerwonka, Trzebucza, Stara Trzcianka lub nazwy zestawione, w których nazwy cieków były członem wyróżniającym, np. Nieciki-Kamiennystok, Jaki-Poniktystok, Ramotowo-Czarnystok.

Dla Jerzego Wiśniewskiego, najwybitniejszego badacza północno-wschodniego Mazowsza, było oczywiste, że podstawą wszelkich rozważań na temat tutejszego osadnictwa musi być rekonstrukcja krajobrazu geograficznego, w tym nazewnictwa wodnego i dlatego badacz ten starał się ustalić położenie nawet najmniejszych cieków, których nazwy odnotowały źródła pisane ${ }^{3}$. Niestety, przedwczesna śmierć spowodowała, że nie cały badany przez niego obszar został opracowany w równym stopniu. Szkoda też, że wielu późniejszych badaczy nie wykorzystało jego dorobku lub przytaczało powzięte ustalenia mechanicznie, nie wdając się w głębszą ich lekturę. W konsekwencji powołali oni do życia wypaczony obraz spływu wielu mniejszych cieków, mylnie oznaczając ich źródła, bieg, dopływy lub przypisując im niewłaściwe poświadczenia nazw. Popełnione omyłki są przenoszone do kolejnych opracowań kartograficznych, historycznych, archeologicznych oraz toponomastycznych ${ }^{4}$.

Dokumentowanie opisanego stanu rozpocznę od przykładów ilustrujących mylące ustalenia źródeł i górnych biegów kilku cieków. Pierwszy dotyczy Wissy, prawego dopływu Biebrzy (ryc. 1). W APHP za górny bieg tej rzeki uznano jej prawy górny dopływ, przy którym umieszczono na mapie nazwę tej rzeki,

2 APHP, cz. 1 mapy Pisz H-3, Ostrotęka H-4, Ełk J-3, Łomża J-4, cz. 2, s. 342, 344.

J. Wiśniewski (1962; 1975; 1977; 1980; 1982; 1985; 1989).

4 Np. P.A. Dmochowski, A. Sikorski (2010, s. 22) lokalizują wieś Niedźwiadnę u źródeł Wissy, choć leżała ona nad Lodwigówką. Nazwę tej rzeczki autorzy zresztą znali, ale podali ją w błędnym zapisie Lodwigoka. 


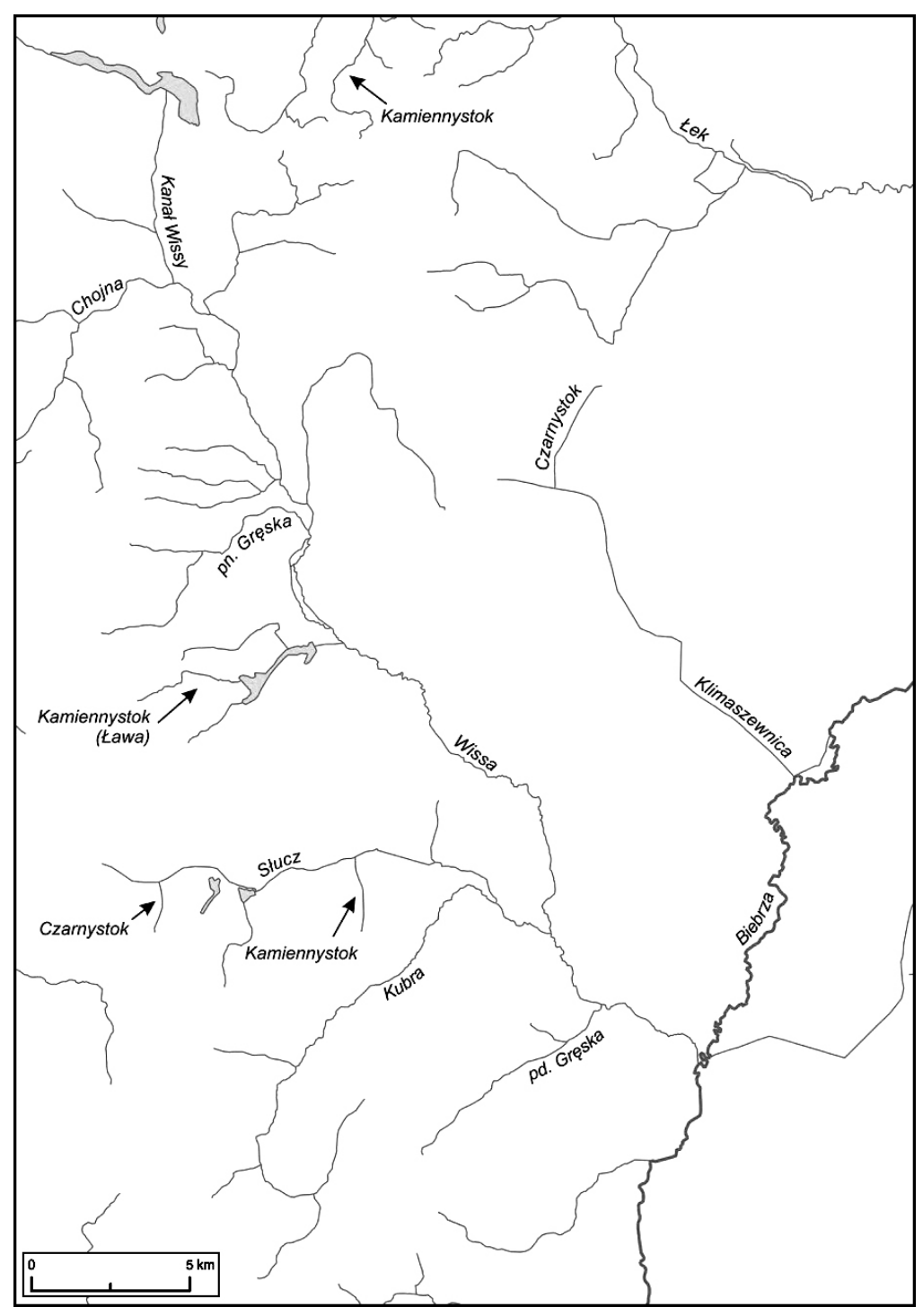

Ryc. 1: Przykłady błędnie zidentyfikowanych cieków w ziemi wiskiej

ale który w katalogu nazwano niekonsekwentnie struga do dopt. spod Dołęg 5 . Dopływ ten kilkakrotnie zmieniał nazwę. Najstarszą z nich, Chojnę (ryc. 1), zapisano już w pierwszej połowie XIV w. (Choyna 1343 r., NKDM II, nr 259;

\footnotetext{
5 APHP, cz. 1, mapa Etk J-3, cz. 2, s. 335 nr 26 29611, podczas gdy Wissa ma nr 26296.
} 
Chogena, Chugena z lat 1396-1397, OF 270a, k. 95v; Kayona lata 1405-1407, OF 270a, k. 94v-95, zapis z 1412 r.; Kogena 1343 r., OF 270a, k. 96, zapis z pierwszej ćwierci XV w.; Choyana, Choyna 1412 r., Lites II, s. 180, 183; Choyna, Cchoyna lata 1412-1414 r., OF 270a, k. 101). Widoczne oboczności pisowni $c h: k$ oraz $j: g$ są powszechne w tekstach średniowiecznych. W tym miejscu trzeba dodać, że zapisy tej nazwy w przekazach z XV w. znane są wyłącznie z krzyżackich opisów rzekomej granicy mazowiecko-krzyżackiej lub z przekazów nawiązujących do układu granicznego z 1343 r. W żadnym z nadań czynionych od początku XV w. w sąsiedztwie tej granicy nazwy tej nie odnotowano. Zamiast niej w źródłach pisanych pojawia się nowa nazwa — Lodwigowa Struga, później Lodwigówka (in riwlo dicto Lodwigowa Strzuga 1426 r., PPr V, nr 361; Lodwigowka 1428 r., PPr V, nr 683). W pierwszej połowie XIX w. na mapie Kwatermistrzostwa (Kol. V Sek. I) zarejestrowano dwie inne jej nazwy: dla górnego biegu Wilcieniec, a dla dolnego Chajewo. Ta ostatnia nazwa to ślad po zaginionej osadzie młyńskiej Chajewo, powstałej w drugiej ćwierci XV w. ${ }^{6}$ M. Biolik zna wyłącznie poświadczenia Lodwigówki (2005a, s. 111-112).

W rzeczywistości prawdziwe źródło Wissy znajdowało się na północ od granicy mazowiecko-krzyżackiej wyznaczonej w 1343 r. i na południe od Jeziora Borowego, leżącego po stronie krzyżackiej, jednak prowadzone przez lata prace hydrotechniczne całkowicie zatarły tu dawny układ wodny. Dlatego też w APHP właściwy górny bieg tej rzeki nazwano Kanałem Wissy (ryc. 1) ${ }^{7}$. O tym, że autorzy tego opracowania pomylili górny bieg Wissy z jej dopływem Chojną/Lodwigówką, jasno wynika z zapisów: die Chugena in die Wusse velt (1396-1397 r., OF 270a, k. 95v) i vbi Lodwigowka et Wissza simul confluunt (1426 r., PPr V, nr 327).

Pozostańmy przy prawych dopływach Wissy. W „Hydronimii Wisły” (1965, nr 466) i w opracowaniu M. Biolik (2005a, s. 173-174) mylnie uznano, że prawym jej dopływem w dolnym biegu jest Slucz (w dolnym biegu zwana Matlakiem), do której z prawej strony uchodzi Kubra (dzisiejsza Przytulanka), podczas gdy jest akurat odwrotnie - to Stucz (ryc. 1) jest lewym dopływem Kubry i to ta rzeka wpada do Wissy, o czym świadczy zapis z lat 1414-1425 (około 1456 r.) circa fluvium Vissa cum una rippa, ubi influit Kubra (MK 3, 24). Tak postrzegano tutejszą hydrografię i hydronimię jeszcze w lustracji z 1660 r., skoro podano, że młyn należący do Radziłowa leży „,na rzece Kubrzenicy”. Obecna nazwa tej rzeczki - Przytulanka, która zastąpiła Kubrę, pojawia się efemerycznie w końcu XV w. (1481 r. penes torrentem przithulanka, MK 5, 83), ale dalej wymieniona jest razem z Kubra (Kubra cum Przythulanka). Ten ostatni

6 Por. Wiśniewski (1975, s. 86, 182-183).

7 APHP, cz. 1, mapa Etk J-3, cz. 2, s. 335 nr 262962.

8 Lmaz 1660-1661, s. 166. W akcie nadającym prawa miejskie Radziłowowi w 1466 r. wspomniano o młynie miejskim położonym na Słuczy (KL, nr 216). 
zapis każe się zastanowić, czy początkowo nazwa Przytulanki nie odnosiła się do jednego z dopływów Kubry płynącego w sąsiedztwie Przytuł. Pojawienie się nazwy Przytulanka miało związek ze zmianą między 1418 a 1424 r. nazwy wsi Kietczewo, założonej nad Kubrą, na Przytuty (Przytula 1436 r., MK 335, 68)9. Na stałe Przytulanke zamiast Kubry do nazewnictwa wodnego wprowadzono dopiero w latach sześćdziesiątych XX w.

W APHP cały bieg Słuczy wraz z ujściowym odcinkiem Kubry nosi już nazwę Matlak ${ }^{10}$, powstałą w dobie nowożytnej i omyłkowo naniesioną na ujściowy odcinek Wissy na mapie von Steina z końca XVIII w. ${ }^{11}$ Utworzono ją zapewne od nazwy osobowej Matlak ( $<$ Matla $<$ Maciej $)^{12}$, która mogła być przezwiskiem młynarza oraz nazwą któregoś z tutejszych młynów ${ }^{13}$ i była przydana tylko ujściowemu odcinkowi Słuczy.

Kolejny przykład odnosi się do Czetny (Cetny), prawego dopływu Narwi, którą w „Hydronimii Wisły” (1965, nr 548) uznano za ciek niezlokalizowany (ryc. 2). Rzeczka ta ma źródło koło wsi Kołaki-Wietrzychowo, co jednoznacznie potwierdza nadanie w 1417 r. dla Dobiesława z Kołaków 40 włók zwanych Wietrzychowo, położonych nad górną Czetną (Wyetrzyichowo... super fluvio Czethna, MK 3,117v), a ujście przy wsi Włodki.

Z inną sytuacją mamy do czynienia w przypadku Małej Sokotdy, zwanej później Sokołdka Ladzka, prawego dopływu Sprząśli (obecnie Supraśli). Jej nazwę znamy od 1358 r. (ad verticem rivuli seu fluminis Maleysucholdi, NKDM III, nr 24), ale próżno jej szukać w „Hydronimii Wisły” (1965, nr 422). Rzeka ta wypływała z bagna w pobliżu późniejszej wsi Oleszkowo. Obecnie powszechnie identyfikuje się ją z Czarną, nazywając jej górny bieg Czarna Rzeczka i oznaczając jej źródło koło tejże wsi ${ }^{14}$. Tymczasem zapis z 1529 (1536?) r. jednoznacznie mówi o tym, że wówczas Czarna nazywano jedynie górny, lewy dopływ Małej Sokołdy: s togo provorot'ja reka Cornaja vstala i pala v Sokoldky Ljadzkuju; toju Černoju do Sokoldki dve mili vdotż (AS I, nr 18, s. 21). Oznacza to, że Czarna ma swe źródło koło miasta Czarna Białostocka (dawniej Czarnej $W s i$, na co wskazuje jednoznacznie jego nazwa i nazwy kilku sąsiednich osad. Zmiany w hydronimii dokonały się zapewne w XVIII w., co dokumentują ręko-

9 Por. Wiśniewski (1975, s. 51).

10 APHP, cz. 1, mapa Łomża J-4, cz. 2, s. 336 nr 26 2968. W dobie nowożytnej rzeka ta nosiła jeszcze inne nazwy, takie jak Plewnina i Rewina, SG, t. 13, s. 617.

11 Mapa von Steina, Sect. 69.

12 Por. Malec (1995, s. 82).

13 Niestety nie udało się tego potwierdzić. W gm. Bakałarzewo, w pow. augustowskim, istnieje natomiast wieś Matlak, znana od schyłku XVIII w., której nazwę utworzono od nazwiska młynarza (wymiennie karczmarza).

14 M. Biolik (2005a, s. 35-36), nie zna też większości najstarszych poświadczeń; APHP, cz. 1, mapa Biatystok K-4, cz. 2, s. 326, nr 26166. 


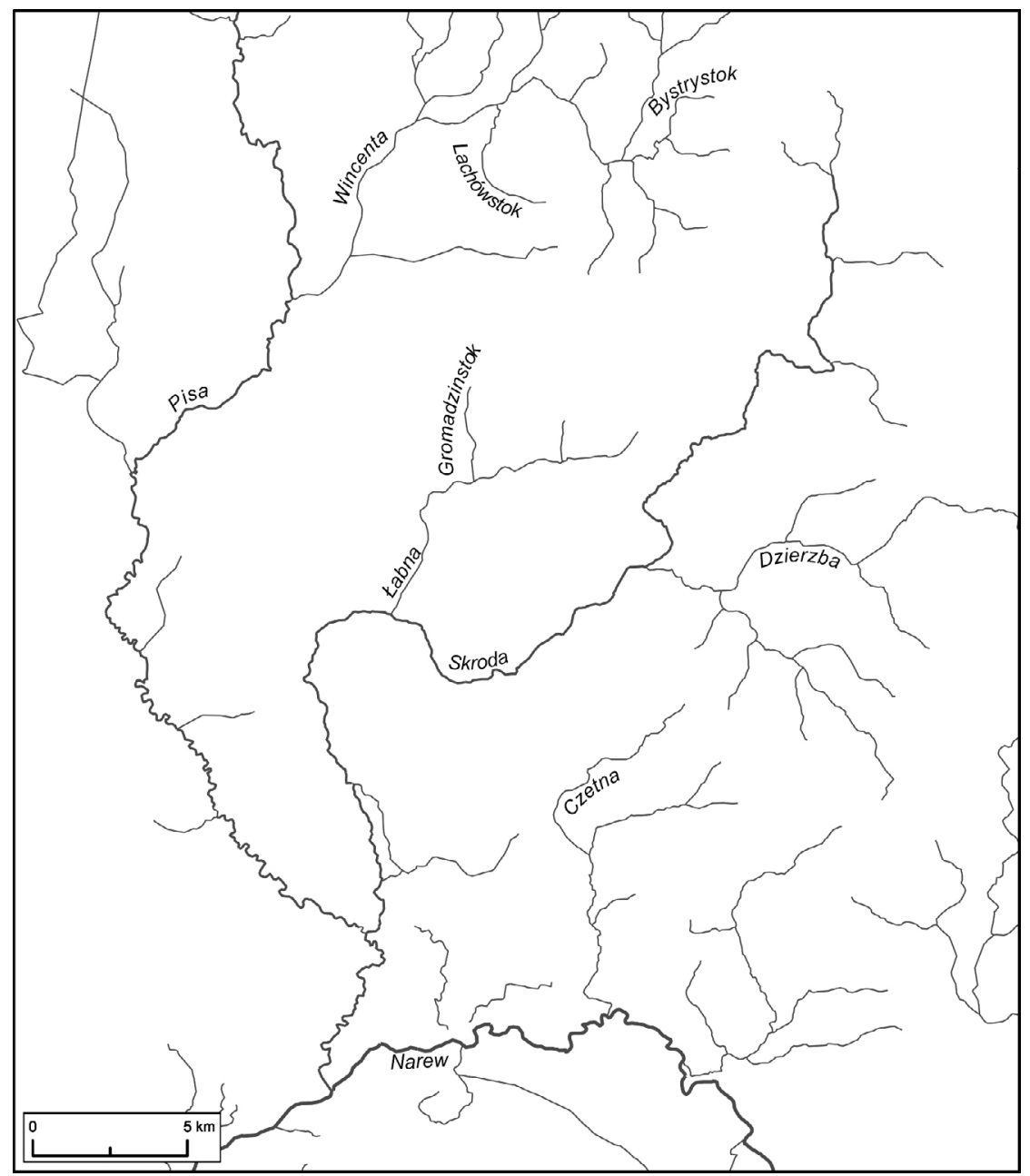

Ryc. 2. Przykłady błędnie zidentyfikowanych cieków w powiecie kolneńskim ziemi łomżyńskiej

piśmienne mapy Karola Perthéesa z 1795 r. ${ }^{15}$ i von Steina z lat $1795-1800^{16}$. Na mapie województwa podlaskiego Perthéesa cały bieg Małej Sokołdy nosi już nazwę Czarna. Tymczasem na nieporównanie dokładniejszej mapie von Steina nazwę Czarna nosi tylko górny bieg Małej Sokołdy, natomiast górny bieg dawbłędny.

${ }^{15}$ K. Perthées (1795). Należy tu dodać, że obraz ukazanej na niej hydrografii jest wyjątkowo 16 von Stein, Sect. 81-82. 
nej Czarnej zwie się Jurczycho (obecnie wymiennie jest nazywany Czapielów$\left.k q^{17}\right)$. Następnie, poczynając od połączenia się obu cieków koło dworu zwanego wówczas Ratowice (obecnie Ratowiec), dalszy bieg Małej Sokołdy nadal zwie się Sokolda / Sokolka. Tak więc nowożytne zastąpienie nazwy Mała Sokołda nazwą Czarna nie odpowiada pierwotnemu postrzeganiu tutejszej hydrografii.

Na jeszcze bardziej zawiłą sytuację natrafiamy w ziemi liwskiej w przypadku Czerwonki (nr 3), lewego dopływu Liwca (dawniej Liwa) i jej dopływów. Nazwa tej rzeczki pojawia się w 1417 r. (Czirwonka, MK 3, k. 113v, kopia z lat 14561459), następnie Cerwonka (1432 r., PPr VI, nr 401), Czerwonka (1452 r., MK 4, k. 8v-9, kopia z lat 1455-1459), Cirwonka (1525 r., MK 339, k. 115) i w 1565 r. w zwrocie na rzece Czerwoncze (Lmaz. II, s. 178). Ciek bierze początek koło wsi Roguszyn Stary, płynąc przez wsi Czerwonka, Orzechów Stary, OrzechówFilipy, Wąsosze, Strupiechów, Krypy(-Mścichy) oraz Karczewiec. Jego ujście znajduje się koło zanikłej w XIX w. osady młyńskiej Ryszki ${ }^{18}$. Obecnie zwie się on Struga, co znalazło odzwierciedlenie w „Hydronimii Wisły”, w której nazwę Czerwonki przydano jedynie górnemu jego biegowi (1965, nr 408). W tym samym opracowaniu prawy dopływ tej rzeczki o zanikłej nazwie Grudówka, poświadczonej w 1445 i 1515 r. (Grudowka, MK 3, 326, kopia z lat 1455-1459 i MK 41, 48v; MK 339, 129), uznano błędnie za nieoznaczony lewy dopływ Liwca. Koszewnicę natomiast, poświadczoną od 1483 r. (Coschewnycza, MK 5, 210), będącą lewym dopływem Grudówki, mylnie określono jako lewy dopływ innej Czerwonki (Grochowski Potok), prawego dopływu Liwca, uchodzącej w Węgrowie, już w ziemi drohickiej (1965, nr 409) ${ }^{19}$. Równie błędny jest obraz Czerwonki w atlasie historycznym Mazowsza (AHPMaz.). Zamiast jej nazwy, pojawia się wyłącznie nazwa Koszewnica, do tego przydana Grudówce ${ }^{20}$.

Wymienione potknięcia powtórzyła E. Bilut ${ }^{21}$, myląc Czerwonkę z Koszewnicą oraz traktując Grudówkę jako dopływ Liwca. Kolejna pomyłka tej badaczki polegała na tym, że nazwę młyna Nadolnego, położonego na Czerwonce, znaną z około 1525 r. (zapis odnosi się do 1512 r. molendinum suum, quod habet in fluvio dicto czerwonka, alias Nadolny, MK 32,171v), uznała za oboczną nazwę Czerwonki (1995, s. 162-163, 49). Był to skutek niezrozumienia zapisu, w którym przestawiono szyk zdania, co jest częste w przekazach źródłowych z tego okresu.

17 APHP, cz. 1, mapa Bialystok K-4, cz. 2, s. 326 nr 261662.

18 Wieś jest jeszcze oznaczona na mapie Kwatermistrzostwa (Kol. V Sek. IV), podobnie jak nazwa Czerwonki.

19 Por. W. K.[opernicki] (1883, s. 26); też APHP, cz. 1, mapa Siedlce J-6, cz. 2, s. 382 nr 26 6858.

${ }^{20}$ Te i inne błędne ustalenia zweryfikowano w publikacji M. Piber-Zbieranowska, A. Salina, przy współpracy E. Kowalczyk-Heyman (2017); por. też E. Kowalczyk-Heyman (2017).

21 E. Bilut (1995, s. 162-163 pod nazwą Struga (9) i s. 49). 
Kolejne rozbieżności pojawiły się w APHP. Czerwonka nosi tu nazwę Strugi, a przyjęte jej źródło i górny bieg są w rzeczywistości źródłem i spływem Grudówki. Nazwę Czerwonka przypisano wyłącznie jej prawemu, górnemu, bezimiennemu dopływowi, wypływającemu między wsiami Pniewnik i Nojszew, podczas gdy prawdziwemu górnemu biegowi przydano określenie Dopływ z Roguszyna, natomiast Koszewnicę nazwano Dopływem spod Skarżyna ${ }^{22}$.

Wymienione błędy nie pozostały bez wpływu na opracowanie Kazimierza Pacuskiego poświęcone ziemi liwskiej. Badacz ten uznał Grudówkę za prawdopodobnie oboczną nazwę Czerwonki lub Koszewnicy, jakoby lewego dopływu Liwca, po czym niekonsekwentnie określił Koszewnicę jako prawy dopływ Czerwonki (Pacuski, s. 60, 85), wszystko niezgodnie z jednoznaczną wymową źródeł pisanych i najstarszych map topograficznych.

Na równie zagmatwaną sytuację natrafiamy w literaturze przedmiotu w przypadku rzeczek Bojmi, Łukawicy, Trzebuczy i Trzcianki, płynących blisko siebie w ziemi liwskiej. Opisane niżej pomyłki odnośnie do tych cieków są tym bardziej niezrozumiałe, że nad częścią z nich powstały wsie, które do dziś noszą nazwy ponowione od nazw tych cieków lub też od których cieki przybrały później nową nazwę (np. Wity > Witówka).

Pierwsza rzeczka, Bojmia (ryc. 3), ma źródło na południe od Ryczołka, a ujście do Witówki II, lewego dopływu Kostrzynia, koło wsi Porzewnica, na południe od Oleksina. Oba cieki, na części spływu, wyznaczały południową granicę ziemi liwskiej. Najstarsze poświadczenie nazwy Bojmi pochodzi z $1471 \mathrm{r}$. i brzmi Boymya (MK 5, 157v)23. Obecnie rzeczka nosi nazwę Trytwa. W „Hydronimii Wisły" oznaczono ją jako niezlokalizowany lewy dopływ Kostrzynia, lewego dopływu Liwca (nr 407). E. Bilut przypisała obie nazwy dwóm różnym ciekom: Bojmię omówiła błędnie pod Gawrońcem, myląc ją tym samym z Trzebucza, lewym dopływem Kostrzynia, natomiast Trytwę utożsamiła z Witówka II (południową), lewym dopływem Kostrzynia, płynącym w ziemi czerskiej (1995, s. $16,45-46,173,188)$.

Kolejna rzeczka, Łukawica (ryc. 3), wypływa koło Witów, a ujście ma na północ od Oleksina. Jest lewym dopływem Kostrzynia. Jej pierwotna nazwa została poświadczona w 1466 r. jako Lucavycza i Lukawycza (kopia z 1493 r., MK 18, 61 i MK 9, 191v). Obecnie w użyciu są dwie nazwy: Witówka I (północna) i Kałuska. W „Hydronimii Wisły” uznano ten ciek za niezlokalizowany lewy dopływ Kostrzynia, dopuszczając identyfikację z Witówką I (nr 407). E. Bilut omówiła go natomiast pod Wit(k)ówka II, myląc ponadto z Trzcianką (1995,

${ }^{22}$ APHP, cz. 1 mapa Warszawa Wsch. H-6, cz. 2, s. 381-382 nr 26 6852, 26 68524, 2668522 i 26685242 .

${ }^{23}$ Nazwa miejscowa Bojmie znana jest już od 1220 r., KK, nr 206. 


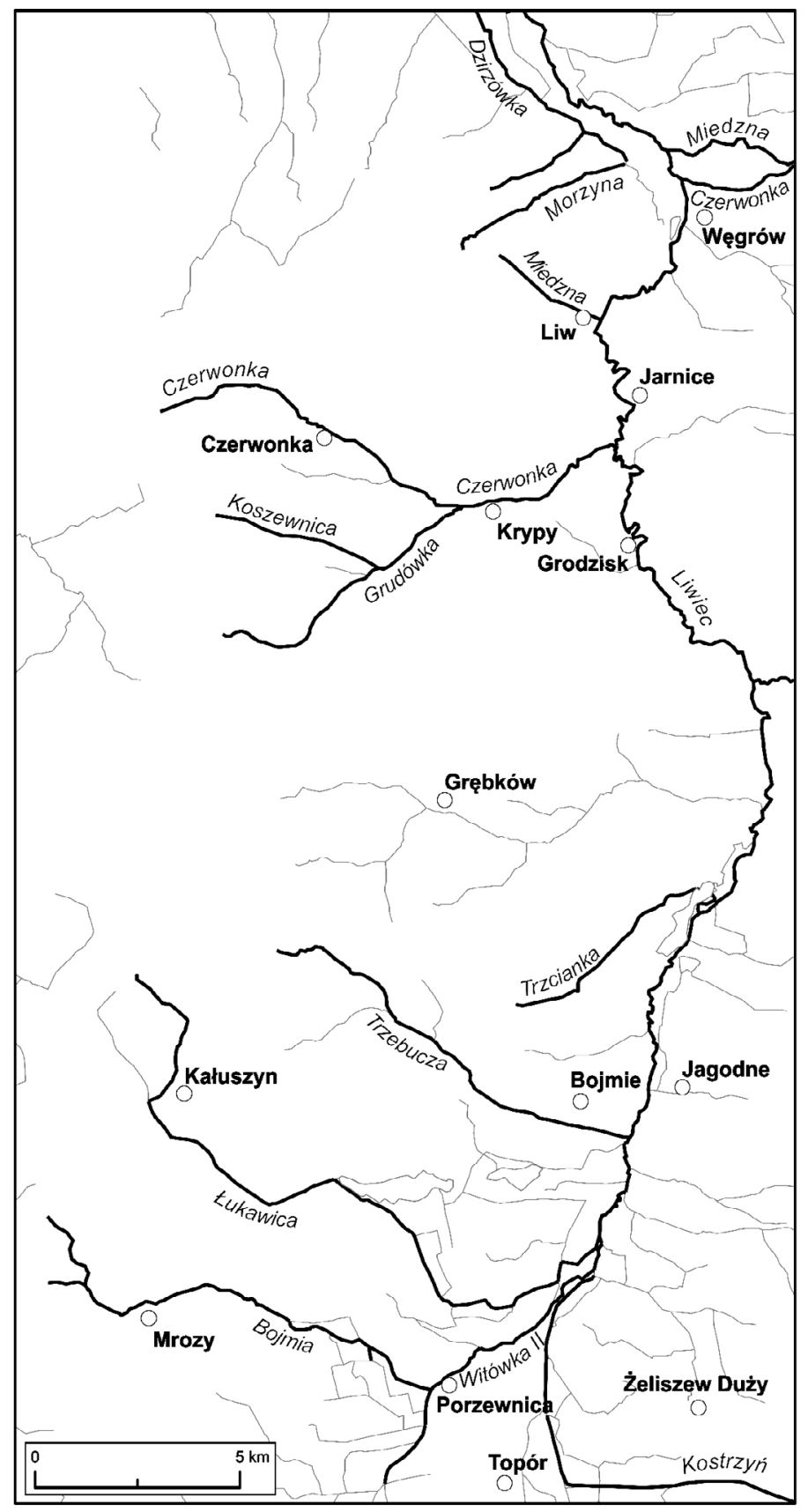

Ryc. 3: Przykłady błędnie zidentyfikowanych cieków w ziemi liwskiej 
s. 98, 187-188). I tu ciekawostka. Na mapie Antona Meyera von Heldensfelda (1801-1804) ciek ten nosi nazwę Kostrzyń i taką świadomość mają do dziś mieszkańcy okolicznych wsi.

Tymczasem Trzcianka (ryc. 3), poświadczona od 1467 r. w zapisie Thrcyan$k a$ (kopia z 1556 r., MK 90, 68v), to lewy dopływ Kostrzynia, wypływający na południe od Starej Trzcianki i uchodzący w Suchej. W „Hydronimii Wisły” błędnie utożsamiono ją z Gawrońcem (nr 407). E. Bilut pomyliła ją natomiast z Wit(k)ówką II i Łukawicą (1995, s. 174, 187-188). W APHP nazwano ją Doplywem spod Trzcianki Starej ${ }^{24}$.

Najstarsze poświadczenia Trzebuczy (ryc. 3), obecnie zwanej Gawrońcem, kolejnego lewego dopływu Kostrzynia, wypływającej koło Wąsów i uchodzącej na południe od Bojmia, pochodzą z 1467 r. i brzmią Strzebnycza (kopia z 1556 r., MK 90, 68v) oraz z 1471 r. Trzebvcza (kopia z 1525 r., MK 41, 43v). W „Hydronimii Wisły” ciek ten uznano za niezlokalizowany lewy dopływ Kostrzynia (nr 407), a E. Bilut omówiła ją pod Gawrońcem, ale pomyliła z Bojmią (1995, s. 45-46).

Niekiedy trudności z identyfikacją rzek wynikają z jednostkowego poświadczenia ich nazw. Przykładem jest Wartopnik, prawy dopływ Moszczony, lewego dopływu Bugu, w ziemi liwskiej. Ciek ten wypływa na południe od Leśników i płynąc przez około $11 \mathrm{~km}$ uchodzi na wschód od Podbali. Poświadczenie jego nazwy, Warthopnyk, pochodzi z 1477 r., kiedy to książę Konrad III sprzedał Stanisławowi i Mikołajowi, synom Piotra z Kątów, 20 włók lasu Połazie, po obu stronach tej rzeki, koło Lisich Jam czyli Jaźwin, między Korytnicą i Rabianami(-Moszczoną) (MK 5, 182av; potwierdzenie nadania w 1539 r., MK 60, 57$57 \mathrm{v})$. Nazwa tej rzeczki, w zniekształconej wersji Jartopnik, pojawia się ponownie u schyłku XIX w. w opracowaniu Tymoteusza Łuniewskiego (1881, s. 455), w którym jest odnotowana dla jej dolnego odcinka. Obecnie nazwa Wartopnik używana jest dla oznaczenia lasu w górnym biegu tego cieku, na prawym jego brzegu, na północny zachód od Lipnik oraz w formie zniekształconej Jartopnik dla łąki w dolnym jego biegu, na zachód od wsi Moszczona.

W „Hydronimii Wisły” ten ciek uznano błędnie za bezpośredni dopływ Liwca między Korycianką a Moszczoną (nr 409), co powtórzyła E. Bilut (1995, s. 183). K. Pacuski nie podał dokładnej lokalizacji, dopuszczając, że może to być dopływ Gołębnicy lub Korycianki (s. 179-180). Trudności w ustaleniu jego spływu wynikają z faktu, że na skutek obniżenia poziomu wód gruntowych w wielu miejscach ciek ten zanika.

Nie lepiej było z ustaleniem etymologii tej nazwy. E. Bilut wyprowadziła ją od *var(a) — 'woda' i czasownika topić z przyrostkiem -nik, co zanegowali

${ }^{24}$ APHP, cz. I, mapa H-6 Warszawa Wsch., cz. 2, s. 381 nr 2668476. 
Zbigniew Babik i Urszula Bijak, uznając ją za nazwę prasłowiańską, powiązaną z południowosłowiańskim apelatywem oznaczającym 'wir wodny', ale także 'zagłębienie', 'pieczarę', por. polskie wertep (Bijak, 2013, s. 47, 150).

Inny przykład nieprawidłowej lokalizacji jednostkowo poświadczonych cieków odnosi się do Dzirzówki (ryc. 3), lewego dopływu Liwca i jej prawego dopływu Morzyny. Pierwszy ciek ma źródło na południe od Popowa (obecnie Popielewa). Na północ od tej wsi łączy się z Morzyną, mającą źródło na południe od Zawad-Morzyna. Dzirzówka uchodzi do Liwca naprzeciwko Starej Wsi, położonej na prawym brzegu tej rzeki. Na taką lokalizację jednoznacznie wskazują zapisy z 1475 r.: inter fluvium Dzyrzowka dictum et inter fluvium dictum Llyw; inter fluminibus Dzyrzowka et Morzyna; ubi influit Morzyna in Dzyrzowka (MK 5, 180). Tymczasem w „Hydronimii Wisły” (nr 408) i w opracowaniu E. Bilut $(1995$, s. 44, 105) oba cieki są uznawane za osobne dopływy Liwca i błędnie lokalizowane powyżej ujścia Czerwonki do Liwca.

Zarówno toponomastom, jak i historykom dużo kłopotów sprawiła zaginiona, rekonstruowana nazwa Bełczacy Stok (ryc. 4). W zniekształconym zapisie Bielszczany stok (ŹDZ XVII/2, s. 178) 25 $^{25}$ pojawia się w 1426 r. w nadaniu księcia Witolda dla Macieja $z$ Tykocina ${ }^{26}$. Utrudniało to jej identyfikację i spowodowało, że w starszej literaturze przedmiotu nietrafnie uznawano ją za zniekształconą nazwę Biały Stok (obecnie Biała), noszoną przez lewy dopływ Sprząśli (obecnie Supraśli) ${ }^{27}$, a stojącą u podstawy nazwy miasta Białystok i kilku okolicznych osad. Kolejny zapis tej nazwy z 1445 r. (1614 r.) - hereditatem Bielczanczy Stok („Inventarium”, s. 359) ${ }^{28}$, pochodzący z innego nadania dla wspomnianego Macieja, posłużył J. Wiśniewskiemu do jej rekonstrukcji i zlokalizowania noszącego ją cieku w okolicy Tykocina jako prawego dopływu Sliny, lewego dopływu Narwi, płynącego koło wsi Milewo, Kapice i Łopuchowo (1985, s. 11-13). Odmienne propozycje przedstawili Tadeusz Wasilewski (1968, s. 111) i Antoni Oleksicki (1981, s. 31), którzy uznali ten ciek za Bokini(n)stok, lewy dopływ Narwi, co z językowego punktu widzenia jest nie do przyjęcia. Ponadto rzeczka Białystok i pochodne od niej nazwy miejscowe, znajdowały się w dobrach Raczkowiczów i Chodkiewiczów, natomiast Bokini(n)stok w dobrach Gasztołtów, na lewym brzegu Narwi, na południowy zachód od Białegostoku.

${ }^{25}$ Informację tę podał wcześniej P. Bobrovskij (1863, s. 852).

${ }^{26}$ Nie można wykluczyć, że było to tylko potwierdzenie wcześniejszego nadania Janusza I, por. S. Szybkowski (1999, s. 292-283).

${ }^{27}$ Np. J. Glinka (1961, s. 57); dopuszcza to także J. Tyszkiewicz (1968, s. 73); W. Pałucki (1961, s. 48); I. Halicka (1978, s. 13); M. Kondratiuk (1993, s. 20); J. Duma (2003, s. 388).

${ }^{28}$ Zapis pochodzi z regestu dokumentu, w którym Jan Gasztołd nadał tę miejscowość Maciejowi z Tykocina. Aleksander Jabłonowski podał błędny zapis Bielczany stok, ŹDZ XVII/2, s. 135. 


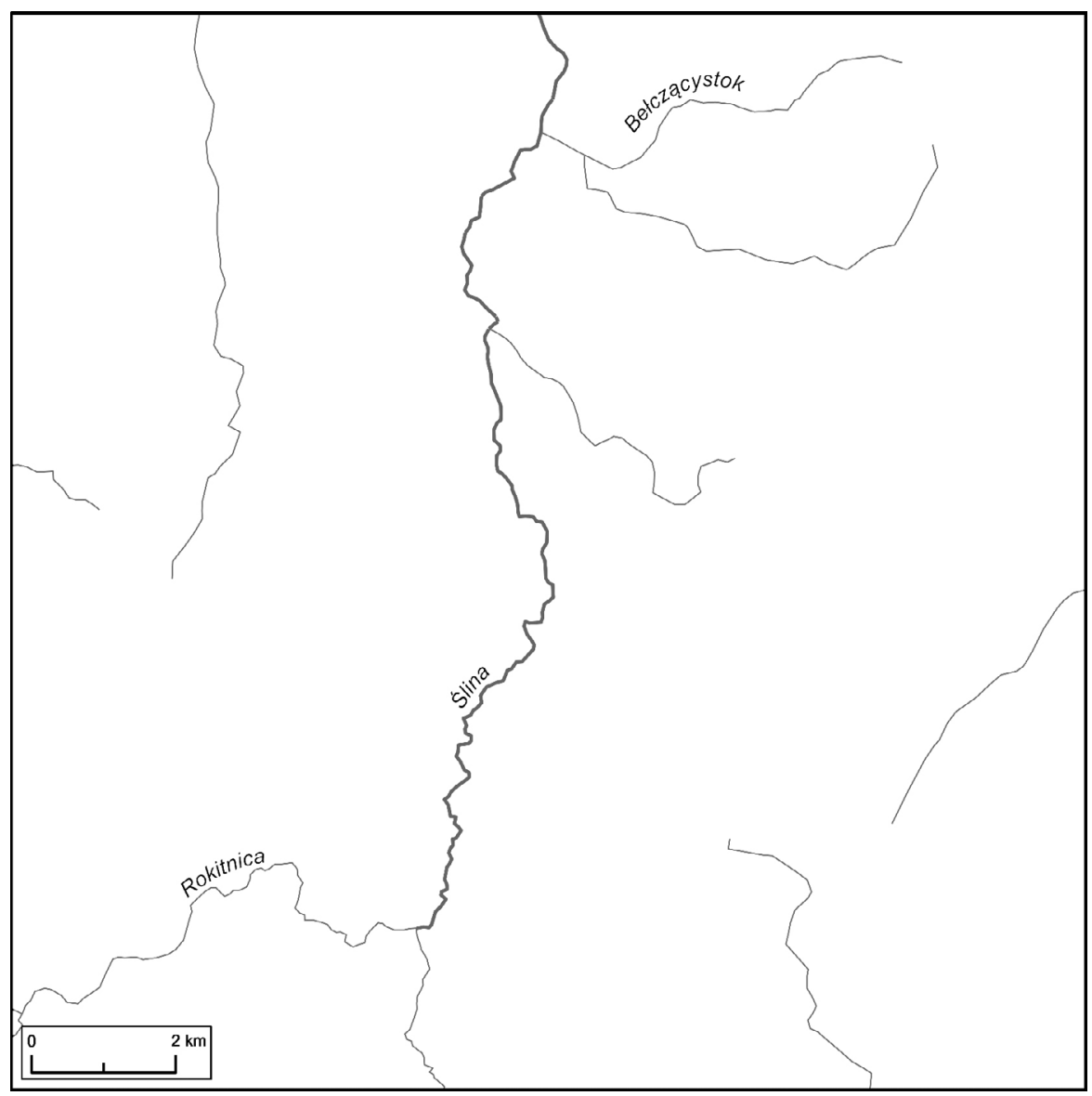

Ryc. 4: Przypuszczalna lokalizacja Bełczacegostoku w okręgu Tykocina

W nazewnictwie wodnym Polski, w tym także omawianego obszaru, często natrafiamy na występowanie identycznych nazw nawet w zlewni tych samych recypientów. To z kolei prowadzi część badaczy, wobec słabej znajomości źródeł pisanych, dziejów i geografii badanego obszaru, do scalania poświadczeń nazw odnoszących się do różnych cieków i złej ich lokalizacji.

Tak się stało w przypadku Miedzny, obecnie Miedzianki, lewego dopływu Liwca, o długości około $3 \mathrm{~km}$, mającej źródło koło wsi Zawady i Połazie, a uchodzącej w Liwie (ryc. 3). Jej nazwa, Miedzna, znana jest od 1565 r. (Lmaz, s. 178, 183). Struga ta w przeszłości dzieliła Stary i Nowy Liw i to motywowało powstanie jej nazwy. W tej funkcji, ale już pod nazwą Miedzianka, znana jest z lustracji dóbr królewskich z 1789 r. (ASK XLVI 176, k. 57). E. Bilut pomyliła 
ją z innym, prawym dopływem Liwca, o tej samej nazwie, uchodzącym na południe od Starej Wsi (ryc. 3), w ziemi drohickiej (1995, s. 102) ${ }^{29}$. W APHP lewy dopływ Liwca nazwano Dopływem w Liwie ${ }^{30}$.

Inny kłopot sprawiały badaczom trzy rzeczki o zanikłych nazwach Kamiennystok, płynące w ziemi wiskiej. Pierwsza z nich to prawy dopływ Rożanicy, prawego dopływu Łeku (obecnie Ełku), będącego prawym dopływem Biebrzy (ryc. 1). Nazwa poświadczona jest jednostkowo w 1491 r. w nadaniu 20 łanów lasu Rożyńsko incipiendo a vertice circumquaque Camyonstok usque ad labencza Struga ibidem super Rosynsko (MK 6, 256). Władysław Pałucki (1961, s. 51) poświadczenie to mylnie przypisał prawemu dopływowi Słuczy, co powtórzyła M. Biolik (2005a, s. 76). Tymczasem ciek ten płynął w lesie Rożyńsko, rozciągającym się znacznie dalej na północ po obu stronach granicy z państwem zakonnym, co jednoznacznie wynika z zapisu i co dokładnie omówił J. Wiśniewski $\left(1965\right.$, s. 40, 165) ${ }^{31}$.

Drugi ciek był albo górnym odcinkiem Ławy, prawego dopływu Wissy, albo jednym z jej górnych dopływów (ryc. 1). Jego zniekształcona nazwa: $\operatorname{Kartio}(n)$ sth(o)k circa granicies Lawsko, pojawia się w 1424 r. (MK 3, 25, zapis z około 1456 r.) w nadaniu dla Jakusza i synów z Niecikowa. Prawidłowe jej brzmienie odtwarza nazwa powstałej tu wsi Nieciki-Kamiennystok (późniejsze Nieciki) ${ }^{32}$, zapisana w 1535 r. - Mathie de Nyecziki Camionistok (MZH, nr 1033). M. Biolik omawia tę nazwę pod Kartionstok nie zdając sobie sprawy, że jest to nazwa zniekształcona (2005a, s. 82), podobnie jak wcześniej Marian Jurkowski (1965, s. 46).

Wreszcie trzeci ciek o nazwie poświadczonej w 1420 r. (nadanie 10 włók super Camonistok, MK 3, 120, zapis z około 1456 r.) był prawym dopływem Słuczy, lewego dopływu Kubry (ryc. 1), prawego dopływu Wissy, ale W. Pałucki uznał go za prawy dopływ Wissy (1961, s. 50-51). Z kolei w „Hydronimii Wisły" (nr 466) błędnie zidentyfikowano go jako prawy dopływ Kubry, podobnie uczynili Marian Jurkowski (1965, s. 46), Adam Wolff i Anna Borkiewicz-Celińska (1971, s. 69) oraz M. Biolik (2005a, s. 76).

W „Hydronimii Wisły” (nr 518) pojawia się ponadto kolejny ciek o tej nazwie jako niezlokalizowany dopływ Skrody, lewego dopływu Pisy, ale nie sposób powiązać go z jakimkolwiek poświadczeniem źródłowym. Moim zdaniem nie istniał.

${ }^{29}$ Por. APHP, cz. 1 mapa Siedlce J-6, cz. 2, s. 382 nr 26682.

30 APHP, cz. 1 mapa Warszawa Wsch. H-6, cz. 2, s. 382 nr 266854.

31 Por. też E. Kowalczyk-Heyman (2013, s. 85-86).

32 I. Halicka (1976, s. 36) błędnie podała, że Nieciki i Mroczki leżą nad tym samym $\mathrm{Ka}$ miennymstokiem. W rzeczywistości są to wsie leżące nad dwoma różnymi ciekami o tej nazwie, w odległości około $7 \mathrm{~km}$ od siebie. 
Inny przykład to dwa cieki o zanikłych nazwach Czarnystok (ryc. 1). Pierwszy był lewym dopływem Klimaszewnicy, prawego dopływu Biebrzy, znanym z poświadczenia z 1452 r. (in Czanystogh, MK 5, 21, zapis z 1472 r.). Drugi był prawym dopływem Słuczy, lewego dopływu Kubry, prawego dopływu Wissy i znamy go z poświadczenia z 1480 r. (super bona Ramothowo Czarnysthok, MK 5, 83v). W. Pałucki (1961, s. 49) połączył poświadczenia nazw obu cieków, a M. Biolik (2005a, s. 38) wymienia wprawdzie obie nazwy, ale również pomyliła poświadczenia odnoszące się do dwóch różnych wsi o tej nazwie założonych nad oboma ciekami: Czarnystok/Czarnestoki, późniejsze Grozimy oraz Ramoty, dawne Ramotowo-Czarnystok.

Podobnie rzecz się ma z dwoma rzeczkami o nazwie Brzozówka. Pierwsza z nich jest lewym dopływem Biebrzy, mającym źródło koło dzisiejszych wsi Brzozówka Ziemiańska i Koronna, uchodzącym dwoma ramionami koło wsi Karpowicze i Dolistowo Stare. Jej najstarsza nazwa brzmiała Wielka Struga i jest poświadczona w 1358 r. w zwrocie ad Vschewelikey strugy (NKDM III, nr 24). W 1529 (1536?) r. jest to już Berozovaja (AS I, nr 20, s. 27). Zmiana nazwy to skutek osadzania od schyłku XV w. ludności ruskiej przez książąt i bojarów litewskich i ruskich na obszarze łuku Biebrzy, odebranym Mazowszu przez Litwę w 1358 i 1398 r.

Drugi ciek o tej nazwie płynął wśród bagien koło wsi Gać-Brzozowo (obecnie Gackie), Łoje-Brzozowo (obecnie Łojki) i Mścichy-Brzozowo (obecnie Brzozowo) i był lewym dopływem Klimaszewnicy, prawego dopływu Biebrzy. Najstarsze poświadczenia jego nazwy pochodzą z $1422 \mathrm{r}$. - in ortu rivuli Brozowka vulgariter dicti cum utraque rippa in terra wiznensi (MK 3, 84, kopia z około 1456 r.), 1422 r. — nadanie 20 włók in Brzozowka Nastoczech wulgariter dicti (MK 3, 91, kopia z około 1456 r.) i z około 1418 r., nadanie 30 włok Brzozowo dicti super rivulo Brzozowka cum utraque rippa (MK 3,119v, kopia z około 1456 r.) $)^{33}$. W „Hydronimii Wisły” (nr 464) ciek ten opisano jako zaginiony, lewy lub prawy dopływ Klimaszewnicy, prawego dopływu Biebrzy, dopuszczając identyfikację z nazwą Stok, która pojawia się w drugim poświadczeniu. W opracowaniu M. Biolik określenie Nastoczech przypisano błędnie pierwszej rzece $^{34}$, a ponadto poświadczenie z 1515 r. odnoszące się do Brzozówki, lewego dopływu Biebrzy, przypisano jeszcze innej Brzozówce płynącej koło Rajgrodu ${ }^{35}$.

Jak wspomniano na wstępie, przyczyn przedstawionego stanu w opracowaniach toponomastycznych upatruję w bardzo słabej znajomości dziejów i geografii omawianych obszarów, słabej znajomości łaciny u części badaczy, nieznajomości źródeł archiwalnych i wyrywaniu nazw rzek z kontekstu przekazu

\footnotetext{
33 M. Jurkowski (1965, s. 46) podał błędny zapis z MK 3, 119v.

34 M. Biolik (2005a, s. 28, 29), błędnie odwołując się do P. Zwoliński (1965).

35 M. Biolik (2005a, s. 27).
} 
źródłowego. Osobną przyczyną jest brak weryfikacji ustaleń zawartych w starszych, często miernych opracowaniach toponomastycznych i powielanie zawartych w nich błędów. Daje się to odczuć w przygotowywanym „Elektronicznym słowniku hydronimów Polski”, w którym powtórzono większość wypunktowanych wyżej pomyłek ${ }^{36}$. Można tylko mieć nadzieję, że jest to stan tymczasowy i zostanie skorygowany w ostatecznej wersji tej publikacji. W przypadku APHP podstawą wypunktowanych rozbieżności były dodatkowo kryteria klasyfikacji cieków przyjęte we współczesnej hydrografii, ale nie odpowiadające postrzeganiu tutejszej hydrografii i hydronimii w średniowieczu.

\section{ŹRÓDŁA}

AGAD - Archiwum Główne Akt Dawnych w Warszawie.

AHPMaz. - Atlas historyczny Polski. Mazowsze w drugiej połowie XVI wieku. W. Pałucki (red.). Cz. 1. Mapa, plany. Warszawa 1973.

APHP - Atlas podziału hydrograficznego Polski. Cz. 1. Mapy w skali $1: 200$ 000, Cz. 2. Zestawienie zlewni. H. Czarnecka (red.). Warszawa 2005.

AS - Arheografičeskij sbornik dokumentov, otnosâščihsâ k istorii severo-zapadnoj Rusi, izdavaemyj pri upravlenii Vilenskogo učebnogo okruga, T. 1. Vil'na 1867.

ASK XLVI 176 - Lustracja starostw liwskiego i korytnickiego i wsi Popowo z 1789 r., AGAD.

Heldensfeld - A.M. von Heldensfeld, mapa Galicji Zachodniej. Skala 1:28 800. 1801-1804 (zbiory Pracowni Atlasu Historycznego Polski IH PAN w Warszawie).

Inventarium - Inventarium omnium et singulorum privilegiorum, litterarum, diplomatum, scripturarum et monumentorum quaecumque in Archivo Regni in Arce Cracoviensi continentur. Wyd.

E. Rykaczewski. Berlin-Poznań 1862.

KK - Zbiór ogólny przywilejów i spominków mazowieckich. Wyd. J.K. Kochanowski. Warszawa 1919.

KL — Kodeks dyplomatyczny księstwa mazowieckiego. Wyd. T. Lubomirski. Warszawa 1863.

Kwatermistrzostwo - Topograficzna karta Królestwa Polskiego, skala 1:126 000. Warszawa (1839) 1843.

Lites II - Lites ac res gestae inter Polonos Ordinemque Cruciferorum. T. 2. Wyd. I. Zakrzewski. Poznań 1893.

Lmaz 1565 - Lustracja województwa mazowieckiego 1565. Cz. 2. Wyd. I. Gieysztorowa, A. Żaboklicka. Warszawa 1971.

Lmaz 1660-1661 — Lustracje województwa mazowieckiego XVII wieku. Cz. 2, 1660-1661. Wyd.

A. Wawrzyńczyk. Warszawa 1989.

MK - Metryka Koronna, AGAD.

MZH - A. Wolff, Mazowieckie zapiski herbowe z XV i XVI wieku. Kraków 1937.

N K D M II-III — Nowy Kodeks Dyplomatyczny Mazowsza. Cz. 2. Dokumenty z lat 1249-1355.

Wyd. I. Sułkowska-Kuraś, S. Kuraś, przy współudziale K. Pacuskiego i H. Wajsa, Wrocław 1989;

Cz. 3. Dokumenty z lat 1356-1381. Wyd. I. Sułkowska-Kuraś, S. Kuraś. Warszawa 2000.

${ }^{36}$ Strona internetowa http://eshp.ijp.pan.pl. Dodam, że w opracowaniu tym pojawiają się też błędne informacje odnośnie do genezy hydronimów, np. nazwa Brzozówki, dopływu Klimaszewnicy ma pochodzić od nazwy miejscowej, podczas gdy jest akurat odwrotnie, co wynika z czasu poświadczenia nazwy cieku i daty założenia wsi. Jest też oczywiste, że w nazwie cieku odzwierciedliło się pokrycie terenu, po którym płynął, czyli zagajników brzozowych. 
OF - Ordensfolianten, Geheimes Staatsarchiv Preussischer Kulturbesitz, Berlin-Dahlem.

Perthées - K. Perthées, Mappa szczegulna woiewodztwa podlaskiego, skala 1:225 000, 1795.

PPr V - Metryka Księstwa Mazowieckiego z XV-XVI w. T. 1 Księga oznaczona nr 333 z lat 1417-1429. Wyd. A. Włodarski. Pomniki Prawa, 5. Warszawa 1918.

SG - Słownik Geograficzny Królestwa Polskiego, T. 13. Oprac. B. Chlebowski. Warszawa 1893.

von Stein - Krieges Karte der Provinz Neu-Ost-Preussen. Enthaltend das nunmehrige Plocker und Bialostoker Cammer Departement. Angefertiget in den Jahren 1795 bis 1800, skala 1:33 300 (Staatsbibliothek Berlin, III C, Q 17 030, wersja elektroniczna mapy w zbiorach Zakładu Atlasu Historycznego Polski Instytutu Historii PAN w Warszawie) ${ }^{37}$.

ŹDZ XVII/2 - Polska XVII wieku pod względem geograficzno-statystycznym. T. 6, cz. 2: Podlasie. Wyd. A. Jabłonowski. Źródła Dziejowe, 18/2. Warszawa 1909.

\section{LITERATURA}

Bijak, U. (2013). Nazwy wodne dorzecza Wisły. Potamoniny odapelatywne [Hydronyms of the Vistula River Basin: Appellative-derived Potamonyms]. Kraków: IJP PAN.

Bilut, E. (1995). Gewässernamen im Flussgebiet des Westlichen Bug (Nazwy wodne dorzecza Bugu). Hydronymia Europaea (dalej cyt. HE). 10. W.P. Schmid (red.). Stuttgart: Franz Steiner Verlag.

Biolik, M. (2005a). Gewässernamen im Flussgebiet der Narew von der Quelle bis zur Einmünndung der Biebrza (Teil 1. Die fliessenden Gewässer). Nazwy wodne dorzecza Narwi od źródeł do ujścia Biebrzy (cz. 1: Nazwy wód płynących). HE. 19. W.P. Schmid (red.). Stuttgart: Franz Steiner Verlag.

Biolik, M. (2005b). Gewässernamen im Flussgebiet der Narew von der Quelle bis zur Einmündung der Biebrza (Teil 2. Die stehenden Gewässer). Nazwy wodne dorzecza Narwi od źródeł do ujścia Biebrzy (cz. 2: Nazwy wód stojących). HE. 20. W.P. Schmid (red.). Stuttgart: Franz Steiner Verlag.

Bobrovskij, P. (1863). Materialy dlja geografii i statistikii Rossii [Materials for the Geography and Statistics of Russia]. Cz. 2 Grodnenskaâ guberniâ. S. Petersburg.

Dmochowski, P. A., Sikorski, A. (2010). Rzekomi Piastowie mazowieccy [Alleged Piasts of Mazovia]. Rocznik Polskiego Towarzystwa Heraldycznego nowej serii, 9 (20), s. 11-28.

Duma, J. (2003). Nazwy rzek polskich ze słowiańskim przymiotnikowym określeniem barwy wody [Names of Polish Rivers with the Slavic Adjective Term of the Water's Color]. W: M. Biolik (red.). Metodologia badań onomastycznych [Methodology of Onomastic Research] (s. 385409). Olsztyn: Towarzystwo Naukowe. Ośrodek Badań Naukowych im. Wojciecha Kętrzyńskiego.

Glinka, J. (1961). Zamek obronny w Białymstoku na przełomie XVI i XVII wieku [The Fortified Castle in Białystok at the Turn of the 16th and 17th Centuries]. Rocznik Białostocki, 2, s. 53-100.

Halicka, I. (1976). Nazwy miejscowe środkowej i zachodniej Białostocczyzny. Dzierżawcze, patronimiczne i rodzinne [Place Names of the Central and Western Białystok Region. Possessive, Patronymic and Family]. Warszawa: PWN.

Halicka, I. (1978). Nazwy miejscowe środkowej i zachodniej Białostocczyzny. Topograficzne i kulturowe [Place Names of the Central and Western Białystok Region. Topographical and Cultural]. Warszawa: PWN.

${ }^{37}$ Mapa ta bywa niekiedy przytaczana pod nazwiskiem J.Ch. Textora. 
Hydronimia Wisły [Hydronymy of the Vistula River]. (1965). Cz. 1: Wykaz nazw w układzie hydrograficznym [List of names in the hydrographic system]. Red. P. Zwoliński. Wrocław: Zakład Narodowy im. Ossolińskich.

Jurkowski, M. (1965) Jeszcze o nazwach miejscowych typu Biatystok, Górnystok, Poniktystok [A Word More about Place Names of the Type Bialystok, Górnystok, Poniktystok]. Onomastica, X, s. 45-49.

Kondratiuk, M. (1993). Tajemnice nazw własnych. Nazwy geograficzne od wyrazów stok, stoczek, potok, ponik [Secrets of Proper Names. Geographical Names from the Words stok, stoczek, potok, ponik]. Czasopis. Pismo informacyjno-kulturalne wschodniej Białostocczyzny, 4, nr 4 (28), s. 18-21.

K.[opernicki], W. (1883). Rzeki i jeziora. Tekst objaśniający do mapy hydrograficznej dawnej Słowiańszczyzny, części północno zachodniej [Rivers and Lakes. Explanatory Text to the Hydrographic Map of the Old Slavdom, North-western Part]. Warszawa: Gebethner i Wolff.

Kowalczyk-Heyman, E. (2008). [rec.] M. Biolik, Gewässernamen im Flussgebiet der Narew von der Quelle bis zur Einmündung der Biebrza (Teil I. Die fliessenden Gewässer). Nazwy wodne dorzecza Narwi od źródeł do ujścia Biebrzy (Cz. I: Nazwy wód płynących). Hydronymia Europaea. 19. W.P. Schmid (red.). Stuttgart 2005; (Teil II. Die stehenden Gewässer). Nazwy wodne dorzecza Narwi od źródeł do ujścia Biebrzy (Cz. II Nazwy wód stojących). Hydronymia Europaea. 20. W.P. Schmid (red.). Stuttgart 2005. Onomastica, LII, s. 356-370.

Kowalczyk-Heyman, E. (2013). Dzieje granicy mazowiecko-krzyżackiej (między Pisą a Biebrzą) [The History of the Mazovian-Teutonic Border (Between Pisa and Biebrza)]. Warszawa: Wyd. DiG.

Kowalczyk-Heyman, E. (2017). Średniowieczne i wczesnonowożytne młyny ziemi liwskiej (Młyny na Czerwonce) [Medieval and Early Modern Times Mills of the Liw Area (Mills on the River Czerwonka)]. Studia Geohistorica, 5, s. 156-175.

Łuniewski, T. (1881). Brzegi i dolina rzeki Liwca [The Banks and the Valley of the Liwiec River]. Pamiętnik Fizjograficzny, 1, s. 453-463.

Malec, M. (1995). Nazwy osobowe pochodzenia chrześcijańskiego. Słownik etymologiczno-motywacyjny staropolskich nazw osobowych [Personal Names of Christian Origin. The Etymological-motivational Dictionary of Old-Polish Personal Names]. Cz. 2. A. Cieślikowa, M. Malec, K. Rymut (red.). Kraków: IJP PAN.

Oleksicki, A. (1981). Rozwój przestrzenny i struktura ludności Białegostoku w XVIII w. [Spatial Development and the Structure of the Białystok Population in the 18th Century]. W: A. Wyrobisz (red.). Studia nad społeczeństwem i gospodarką Podlasia w XVI-XVIII w. [Studies on the Society and Economy of Podlasie Region in the 16th-18th Centuries] (s. 31-90). Warszawa: Wydawnictwa UW.

Pacuski, K. (b.r.wyd.). Materiały do słownika historyczno-geograficznego ziemi liwskiej w średniowieczu i w XVI wieku. Hasła fizjograficzne [Materials for the Historical and Geographical Dictionary of the Liv Area in the Middle Ages and in the 16th Century. Physiographic Entries]. Atlas źródeł i materiałów do dziejów dawnej polski [Atlas of Sources and Materials for the History of Ancient Poland], $\mathrm{nr} 4$ (http://atlasfontium.pl/index.php?article=liw_pacuski).

Pałucki, W. (1961). Nazwy miejscowe typu Bialystok, Górnystok, Poniktystok [Place Names of Type Biatystok, Górnystok, Poniktystok]. Onomastica, VII, s. 45-61.

Piber-Zbieranowska, M., Salina, A., przy współpracy Kowalczyk-Heyman, E. (2017). Słownik historyczno-geograficzny ziemi liwskiej w średniowieczu [The Historical-geographical Dictionary of the Liv Land in the Middle Ages]. T. Jurek (red.). Warszawa: IH PAN.

Szybkowski, S. (1999). Dokument wielkiego księcia litewskiego Witolda Kiejstutowicza dla Stanisława Milewskiego z 23 XII 1429 r. [A Document of the Great Lithuanian Prince Witold Kiejstutowicz for Stanisław Milewski from 23 XII 1429].W: B. Śliwiński (red.). Książęta, urzędni- 
cy, złoczyńcy. Gdańskie studia z dziejów średniowiecza [Princes, Officials, Criminals. Gdańsk Studies in the History of the Middle Ages]. T. 6 (s. 303-314). Gdańsk: Officina Ferberiana. Tyszkiewicz, J. (1968). Zarys dziejów okolic Białegostoku [Outline of the History of Bialystok. W: J. Antoniewicz, J. Jok (red.). Studia i materiały do dziejów miasta Białegostoku [Studies and Materials for the History of the Białystok City]. T. 1 (s. 57-80). Białystok: PWN.

Wasilewski, T. (1968). Białystok w XVI-XVII wieku [Białystok in the XVI-XVII Centuries]. W: J. Antoniewicz, J. Jok (red.). Studia i materiały do dziejów miasta Białegostoku [Studies and Materials for the History of the Białystok City]. T. 1 (s. 107-127). Białystok: PWN.

Wiśniewski, J. (1962). Rys dziejów osadnictwa na wschodnim Mazowszu [The History of the Settlement in Eastern Mazovia]. Literatura Ludowa, 6, nr 4/6, s. 11-21.

Wiśniewski, J. (1975). Dzieje osadnictwa w powiecie grajewskim do połowy XVI w. History of the Settlement in the Grajewo County until the mid-16th Century. W: M. Gnatowski, H. Majecki (red.). Studia i materiały do dziejów powiatu grajewskiego [Studies and Materials for the History of Grajewo County]. T. 1 (s. 9-252). Warszawa: PWN.

Wiśniewski, J. (1977). Osadnictwo wschodniej Białostocczyzny — geneza, rozwój oraz zróżnicowanie i przemiany etniczne [Settlements of the Eastern Białystok Region — the Genesis, Development, and Ethnic Diversity and Changes]. Acta Baltico-Slavica, 11, s. 7-80.

Wiśniewski, J. (1980). Zarys dziejów osadnictwa na Białostocczyźnie [Outline of the History of the Settlement in the Białystok Region]. W: S. Glinka, A. Obrębska-Jabłońska, J. Siatkowski (red.). Atlas gwar wschodniosłowiańskich Białostocczyzny [Atlas of the East Slavonic Dialects of the Białystok Region]. T. 1 (s. 14-27). Wrocław: Zakład Narodowy im. Ossolińskich.

Wiśniewski, J. (1982). Kształtowanie się nazw wsi na północno-wschodnim Mazowszu do końca XIV i w XV wieku [Formation of the Names of Villages in North-eastern Mazovia until the End of the 14th Century and in the 15th Century]. Zeszyty Naukowe Wydziału Humanistycznego Uniwersytetu Gdańskiego. Filologia Polska. Prace Językoznawcze, 8, s. 89-98.

Wiśniewski, J. (1985). Początki Białegostoku i okolicznego osadnictwa [Beginnings of Białystok and Surrounding Settlements]. W: H. Majecki (red.). Studia i materiały do dziejów miasta Białegosto$\mathrm{ku}$ [Studies and Materials for the History of the Białystok City]. T. 4 (s. 7-27). Białystok: PWN.

Wiśniewski, J. (1989). Początek i rozwój nowego osadnictwa w ziemi łomżyńskiej w końcu XIV i w XV wieku [Beginning and Development of a New Settlement in the Łomża Land in the Late 14th and 15th Centuries]. Studia Łomżyńskie, 1, s. 19-107.

Wolff, A., Borkiewicz-Celińska, A. (1971). Słownik historyczno-geograficzny ziemi wyszogrodzkiej w średniowieczu [Historical-geographical Dictionary of Wyszogród Land in the Middle Ages]. Wrocław: Zakład Narodowy im. Ossolińskich.

\section{SUMMARY}

\section{ABOUT MEANDERS OF IDENTIFICATION OF MEDIEVAL RIVER NAMES} IN THE NORTH-EASTERN AND EASTERN MAZOVIA REGION

In the paper, on the basis of several dozen examples of hydronyms from eastern and north-eastern Mazovia, the erroneous attribution of written sources and, as a consequence, their incorrect identification and location were shown. These kinds of mistakes can be found in toponymical, hydrographical and historical publications. It is the result of taking attestations from the context of the source, poor knowledge of the history and the geography of the studied area, as well as the poor knowledge of Latin and the lack of verification of hypotheses found in older literature.

Keywords: hydronymy, Eastern Mazovia, North-eastern Mazovia 